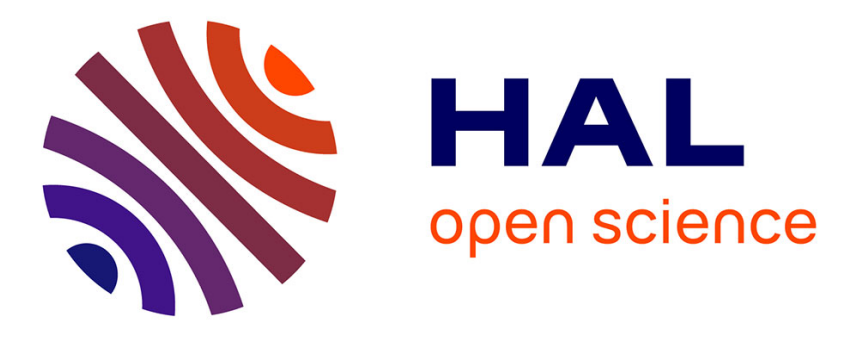

\title{
Chemical Composition, Antioxidant and Antimicrobial Activities of the Essential Oils of Three Algerian Lamiaceae Species
}

Khadidja Houda Benabed, Nadhir Gourine, Mohamed Ouinten, Isabelle Bombarda, Mohamed Yousfi

\section{To cite this version:}

Khadidja Houda Benabed, Nadhir Gourine, Mohamed Ouinten, Isabelle Bombarda, Mohamed Yousfi. Chemical Composition, Antioxidant and Antimicrobial Activities of the Essential Oils of Three Algerian Lamiaceae Species. Current Nutrition and Food Science, 2017, 13 (2), pp.97 - 109. 10.2174/1573401313666170104105521 . hal-01777681

\section{HAL Id: hal-01777681 \\ https://hal.science/hal-01777681}

Submitted on 25 Apr 2018

HAL is a multi-disciplinary open access archive for the deposit and dissemination of scientific research documents, whether they are published or not. The documents may come from teaching and research institutions in France or abroad, or from public or private research centers.
L'archive ouverte pluridisciplinaire HAL, est destinée au dépôt et à la diffusion de documents scientifiques de niveau recherche, publiés ou non, émanant des établissements d'enseignement et de recherche français ou étrangers, des laboratoires publics ou privés. 



\title{
Chemical Composition, Antioxidant and Antimicrobial Activities of the Essential Oils of Three Algerian Lamiaceae Species
}

\author{
Khadidja Houda Benabed ${ }^{\mathrm{a}}$, Nadhir Gourine ${ }^{\mathrm{a},{ }^{*}}$, Mohamed Ouinten ${ }^{\mathrm{a}}$, Isabelle Bombarda ${ }^{\mathrm{b}}$ and \\ Mohamed Yousfi ${ }^{\mathrm{a}}$
}

${ }^{a}$ Laboratoire des Sciences Fondamentales LSF, Université Amar Télidji, Laghouat, BP. 37G, Laghouat, Algérie; ${ }^{b}$ Laboratoire LISA, Équipe METICA, EA 4672, Université Aix-Marseille, Marseille, France

\begin{abstract}
Background: The present work investigates the chemical composition, the antioxidant and the antimicrobial activities of the Essential Oils (EOs) of three species of the Lamiaceae family gowning in Algeria: Thymus vulgaris L., Thymus algeriensis Boiss. \& Reut. and Mentha pulegium L.

Methods: Essential Oils (EOs) obtained by hydrodistillation of the aerial parts of the studied plants were analyzed by GC and GC-MS. The antioxidant activity of the EOs was determined using two different assays: free radical scavenging activity of $\mathrm{DPPH}^{\circ}$ (2,2-diphenyl-1-picrylhydrazyl) and Phosphomolybdenum reducing power. The EOs were also tested for their antibacterial and antifungal activities against eight pathogenic bacteria (Klebsiella pneumoniae, Pseudomonas aeruginosa, Salmonella typhi, Escherichia coli, Bacillus cereus, Staphylococcus aureus, Methicillin resistant strain of S. aureus "MRSA" and Enterococcus faecalis); a yeast (Candida albicans); and a fungi (Fusarium oxysporum).
\end{abstract}

Results: For DPPH assay, T. vulgaris presented very interesting activity. At the opposite, T. algeriensis (Aflou) and M. pulegium, were the most active EOs in term of Phosphomolybdenum assay. The antimicrobial activity of $T$. vulgaris was found to be the most active EO and exhibited important resistance against most of studied bacteria. For disc diffusion test, the most active EO plant was $T$. algeriensis. Alternatively, and for antifungal activity, T. vulgaris presented the highest value of MFC.

Conclusion: The antioxidant activity test's results showed that the EOs exhibited important reducing powers but weak scavenging activities. On the other hand, it was found that some EO samples have shown very interesting antimicrobial activities. Actually, among the investigated EOs, T. vulgaris presented the strongest antibacterial and antifungal activities.

Keywords: Thymus vulgaris L., Thymus algeriensis Boiss. \& Reut., Mentha pulegium L., DPPH assay, phosphomolybdenum assay, antimicrobial activity, essential oil.

\section{INTRODUCTION}

To cure its ills, man had always relied on animals and plants. These have always been the basis of the traditional systems of medicine for thousands of years and continue to date to provide new remedies [1]. Recently, the introduction of traditional medicine, as an alternative form, as well as the development of microbial resistance to antibiotics has led researchers to study the antimicrobial activity of medicinal plants [2]. On the other hand, the different synthetic antioxidants used in food, were suspected to have negative health effects. It is for this reason that the interest for the study of natural products such as antioxidants is increasingly important. Thus, various sources of antioxidants of plant origin have been studied in recent years [3].

The use of essential oils as functional ingredients in foods, drinks, toiletries and cosmetics is gaining momentum [4]. Additionally, the use of essential oils is becoming popular to increase the shelf-life of food products, since consumers are more conscious about the health problems caused by several synthetic preservatives $[5,6]$.

The purpose of this research was to investigate, firstly the chemical composition and the antioxidant properties of three EOs (T. vulgaris L., T. algeriensis Boiss. \& Reut. and $M$. pulegium L.) collected from two regions in the center of Algeria; and secondly, to examine their antimicrobial activities against eight pathogenic bacteria (Klebsiella pneumoniae, Pseudomonas aeruginosa, Salmonella typhi, Escherichia 
coli, Bacillus cereus, Staphylococcus aureus, Methicillin resistant strain of $S$. aureus "MRSA" and Enterococcus faecalis); a yeast (Candida albicans); and a fungi (Fusarium oxysporum).

Only very few reports on the determination of the antioxidant activity of the essential oil using Phosphomolybdenum assay and applied for of $T$. vulgaris were found in literature [7-9]. For these reports, the antioxidant values are difficult to use for comparison purpose since different methods of expressions or different antioxidant of reference were engaged. In the same context, and as best of our knowledge, there are no reports dealing with the Phosphomolybdenum assay of the EO for $T$. algeriensis Boiss. \& Reut. and $M$. pulegium L. As far as we know, this is the first report that investigates the antioxidant antimicrobial activities of the essential oils of the plants from these regions of collection (Djelfa and Aflou "Laghouat") from Algeria. Furthermore, we have used for the first time a special form of Fusarium oxysporum which was isolated from a fragment of date palm from Ghardaia region to investigate the antifungal activity. In addition, the antioxidant activity of the EOs determined by DPPH and Phosphomolybdenum assays were examined for the first time for these regions. Finally, correlations between chemical compositions of the EOs and their antioxidant and antimicrobial activities were investigated using statistical analysis; this was done in order to determine the nature of the chemical component(s) responsible(s) for the different activities of the EOs.

\section{MATERIALS AND METHODS}

\subsection{Plants Descriptions}

Thymus vulgaris L. is a perennial herb indigenous in central and southern Europe, Africa and Asia. It is widely used in folk medicine in the treatments of variety of diseases such as gastroenteric and bronchopulmonary disorders, as well as due to its anthelmintic, carminative, sedative and diaphoretic properties [10]. It has been reported that its EO possesses numerous biological activities including antiworm, antiseptic, antispasmodic, antimicrobial [11] and antioxidant [12]. In addition, it is a well-known species of the genus Thymus, extensively studied for its chemical and biological activities [13-15].

In Algeria, T. vulgaris is one of the most useful popular remedies in the treatment of respiratory affections (colds, flu, angina) and gastric disorders (dyspepsia, cramps) [16].

Thymus algeriensis Boiss. \& Reut. is the most widespread North African species, endemic to Libya, Tunisia, Algeria and Marocco. Fresh or dried, it is largely used only as a culinary herb. T. algeriensis is also used in traditional medicine, as a fresh or dry seasoning, in respiratory and digestive tube disorders and against abortion [17].

In Algeria, T. algeriensis is used as a treatment for stomachic, diaphoretic, antispasmodic and stimulating. The summits and the young flowering twigs are used. Infusion is useful against all infectious diseases, such as influenza, pneumonia and respiratory tract diseases. It is used in friction in cases of neuralgia and sciatica and as odontalgic on decayed toothache [18].
Mentha pulegium L. is one of the Mentha species commonly known as pennyroyal. It is native species of Europe, North Africa and in Asia Minor and near East. The flowering aerial parts of $M$. pulegium L. has been traditionally used for its antiseptic for treatment of cold, sinusitis, cholera, food poisoning, bronchitis and tuberculosis, and also as antiflatulent, carminative, expectorant, diuretic, antitussive, menstruate. Some pharmacological effect of $M$. pulegium L. essential oil such as abortifacient effect in rat myometrium, cytotoxic activity against different human cell lines and its antioxidant effect were confirmed [19].

In Algeria it is much appreciated, so much so that it is used to prepare a traditional dish: the potato stew with the pennyroyal "Batata Fliou". Its pleasant odor seems to displease some kind of parasites, and its insecticidal power is well established. Formerly, it was burned in fleece infested premises. It was also used as a lotion on the coat of domestic animals to rid them of their parasitic pests [16].

\subsection{Plants Materials Collections}

The study was carried out using four EO samples obtained from three species belonging to the Lamiaceae family: M. pulegium L. (Djelfa), T. vulgaris L. (Djelfa) and T. algeriensis Boiss. \& Reut. (from two different stations: Djelfa and Aflou-Laghouat). Since $T$. algeriensis, wide spreads over a larger region, we have picked up two samples from different locations in order to compare theirs EOs composition differences as well as theirs antioxidant and antibacterial activities behaviors. The different plant samples were collected in 2010 during the flowering stage; (end of May for $M$. pulegium and $T$. algeriensis, and the beginning June for T. vulgaris). Voucher specimens (TV/06/10, TA-AFL/06/10, TA-DJF/06/10, MP/06/10) were deposited in the herbarium of the Fundamental Sciences Research Laboratory at Laghouat University.

\subsection{Essential Oil Extraction}

The different samples of EOs were obtained by hydrodistillation using a Clevenger type apparatus; subsequently the obtained EOs were dried over anhydrous sodium sulfate, and stored in a dark at $4{ }^{\circ} \mathrm{C}$.

\subsection{Essential Oil Analysis}

The GC analysis was performed using a gas chromatograph type Chrompack CP 9002, equipped with a fused silica capillary column DB-5 $(30 \mathrm{~m} \times 0.32 \mathrm{~mm}, 0.25 \mu \mathrm{m}$ film thickness) and Flame Ionization Detector (FID). The carrier gas was nitrogen at a flow rate of $1 \mathrm{~mL} / \mathrm{min}$. The column temperature was programmed from $50{ }^{\circ} \mathrm{C}$ ( 3 minutes $)$ to $250{ }^{\circ} \mathrm{C}$ at $2{ }^{\circ} \mathrm{C} / \mathrm{min}$, and then maintained at $250{ }^{\circ} \mathrm{C}$ for $10 \mathrm{~min}$. The temperatures of the injector and detector were set at $250{ }^{\circ} \mathrm{C}$. Volumes of $1 \mu \mathrm{L}$ of diluted samples $(1: 100 \mathrm{v} / \mathrm{v}$, in ethanol) were injected manually using split less mode. Linear retention indices of the components were calculated using a series of $n$-alkane $\left(\mathrm{C}_{9}-\mathrm{C}_{25}\right)$ analyzed under the same operating conditions as those of the EOs samples.

The GC/MS analysis was performed on an AGILENT 6890 GC/CMSD 5973 equipped with a capillary column UB-Wax $(30 \mathrm{~m} \times 0.25 \mathrm{~mm}, 0.25 \mu \mathrm{m}$ film thickness $)$ and a 70 
eV EI Quadruapole detector. Helium was the carrier gas, at a flow rate of $1 \mathrm{~mL} / \mathrm{min}$. Injector and MS transfer line temperatures were set at $250{ }^{\circ} \mathrm{C}$ and $220{ }^{\circ} \mathrm{C}$, respectively. Column temperature was programmed same as gas chromatography. Diluted samples $(1: 100 \mathrm{v} / \mathrm{v}$, in ethanol) of $1 \mu \mathrm{L}$ were also injected manually using split less mode.

The EOs constituents were identified by comparison of their linear retention indices and mass spectra with those in the computer library (NIST MS Library) and with literature data [20].

\subsection{DPPH Assay (Free Radical Scavenging Activity)}

For this test, the ability of hydrogen donating or radical scavenging was measured using the stable radical DPPH (2,2-diphenyl-1-picrylhydrazyl) [21]. The EOs dilutions were prepared in absolute ethanol, and then $1 \mathrm{~mL}$ of each dilution was added to $1 \mathrm{~mL}$ of a $200 \mu \mathrm{M}$ DPPH solution. The mixtures were incubated in dark for $30 \mathrm{~min}$; afterwards the absorbance was measured at $517 \mathrm{~nm}$ against a blank. The inhibition percentage was calculated using the following formula:

$$
I(\%)=\left(\frac{A_{0}-A}{A_{0}}\right) \times 100
$$

Where:

$A_{0}$ is the absorbance of the control reaction (containing all reagents except the test compound) and $A$ is the absorbance of the test compound.

\subsection{Phosphomolybdenum Assay}

This assay is based on the reduction of Molybdate (VI) to Molybdate (V) by the antioxidant compounds and the formation of a green phosphate/Molybdate (V) complex at acidic $\mathrm{pH}$ with a maximum absorbance at $695 \mathrm{~nm}$ [22]. The EOs samples were diluted in absolute ethanol. An amount of 200 $\mu \mathrm{L}$ of each dilution was mixed with $2 \mathrm{~mL}$ of reagent $(0.6 \mathrm{M}$ sulfuric acid, $28 \mathrm{mM}$ sodium phosphate, and $4 \mathrm{mM}$ ammonium molybdate). The mixture was then incubated in a water bath set at $70{ }^{\circ} \mathrm{C}$ for $90 \mathrm{~min}$ [22]. The absorbance was determined at $695 \mathrm{~nm}$. The results were expressed in terms of ascorbic acid equivalent AEAC.

\subsection{Microbial Strains}

The different samples of EOs were tested against eight bacteria: Klebsiella pneumoniae ATCC 700603, Pseudomonas aeruginosa ATCC 27853, Salmonella typhi (isolate), Escherichia coli ATCC 25922, Staphylococcus aureus ATCC 25923, Methicillin resistant strain of S. aureus ATCC 43300, Bacillus cereus ATCC 11779, Enterococcus faecalis ATCC 29212 ; a yeast: Candida albicans (isolate) and a filamentous fungi Fusarium oxysporum f. sp. albedinis. The fungal species Fusarium oxysporum special form albedinis was isolated from a fragment of date palm provided by the Regional Station of Plant Protection of Ghardaia (Algeria). The culture was then purified by performing a monospore culture.

\subsection{Antimicrobial Tests}

The antimicrobial activity of the different EO samples was screened by the disk diffusion test [23], and then the minimal inhibitory and bactericidal concentrations were determined using a dilution test [24]. The antifungal activity was tested using a direct contact test as described by El Ajjouri et al. [25].

\section{RESULTS}

\subsection{Essential Oil Yield and Chemical Composition}

The yields of the studied EOs were varying from moderate to low values. They were somehow important for $M$. pulegium and T. vulgaris. In the other hand, they were ranging from low to poor values for T. algeriensis (Table 1).

The chemical compositions of the different EO samples are presented in Table 1. For the EO of $T$. vulgaris, thirty two different compounds representing $96.47 \%$ of the total oil were identified, with proportions of monoterpene hydrocarbons and oxygenated monoterpenes equal to $52.98 \%$ and $39.14 \%$, respectively. The major component of this oil was the $\gamma$-terpinene $(25.70 \%)$ followed by thymol $(20.83 \%)$, then $p$-cymene $(20.04 \%)$. The oxygenated compounds were also present in lower amounts than the hydrocarbons: thymol methyl ether $(7.82 \%)$, linalool $(4.76 \%)$ and borneol $(2.54 \%)$. The $\beta$-caryophyllene $(2.28 \%)$ was the main sesquiterpene compound for this EO.

For the EO of pennyroyal (M. pulegium), twenty eight compounds were identified representing $76.38 \%$ of the total EO. The oil was mainly composed of pulegone $(54.92 \%)$, which accounts for almost the majority of oxygenated monoterpenes. Monoterpene hydrocarbons represented only a small fraction of the EO content (2.67\%).

For the case of $T$. algeriensis, forty four components were identified for the sample of Djelfa and thirty three components of that of Aflou (Laghouat), both accounting for 83.30 and $81.06 \%$ of the total EOs, respectively. Camphor was the predominant compound in the sample of Aflou (Laghouat) with a percentage of $17.68 \%$, this content agrees with the results of Amarti et al. [26] and Zouari et al. [27] who have detected camphor as major compound for $T$. algeriensis from Morocco and Tunisia, respectively. The sample of Djelfa was predominantly composed of $\alpha$-terpinenyle acetate $(27.32 \%)$, a compound completely absent in the sample of Aflou. Camphor was also present, but with a lower content $(10.77 \%)$ than recorded for the sample of Aflou (Laghouat). The eucalyptol was one of the major compounds in the EO sample of Aflou (10.04\%), whereas it represented only $2.47 \%$ for the sample of Djelfa. The EO of Aflou sample showed a high content of monoterpene hydrocarbons (41.29\%) compared to that of Djelfa (13.71\%), with a predominance of camphene $(8.73 \%), \alpha$-pinene $(7.84 \%)$ and myrcene $(6.95 \%)$. On the other hand, the two samples showed almost equal percentages of borneol (5.58 and $5.68 \%$ ). Sesquiterpenes were minor compounds in the EOs of the two regions with a total percentage of 5.46 and $3.04 \%$ for Djelfa and Aflou respectively. 
Table 1. Chemical composition of the essential oil samples: Thymus vulgaris, Thymus algeriensis and Mentha pulegium.

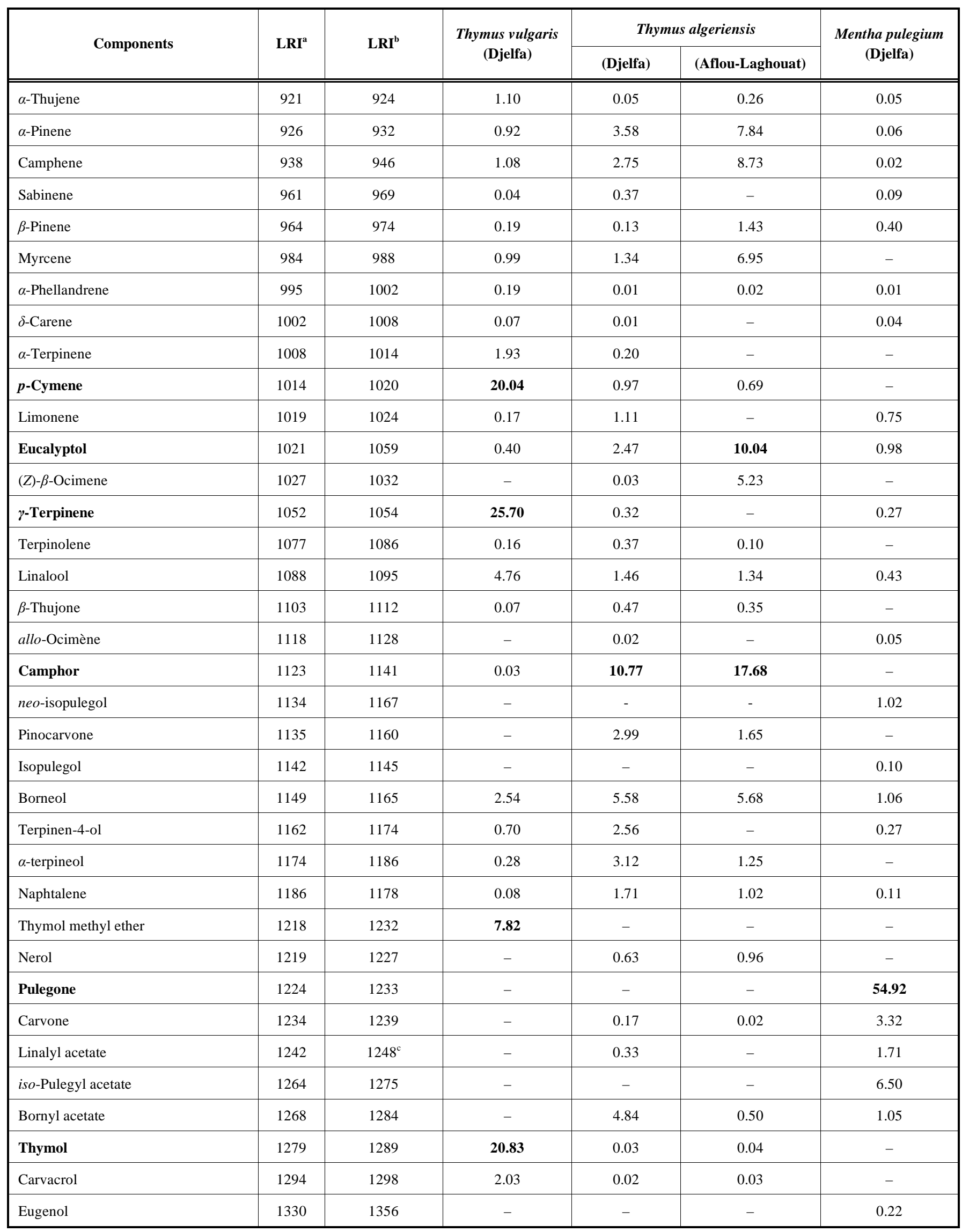


Table 1. contd...

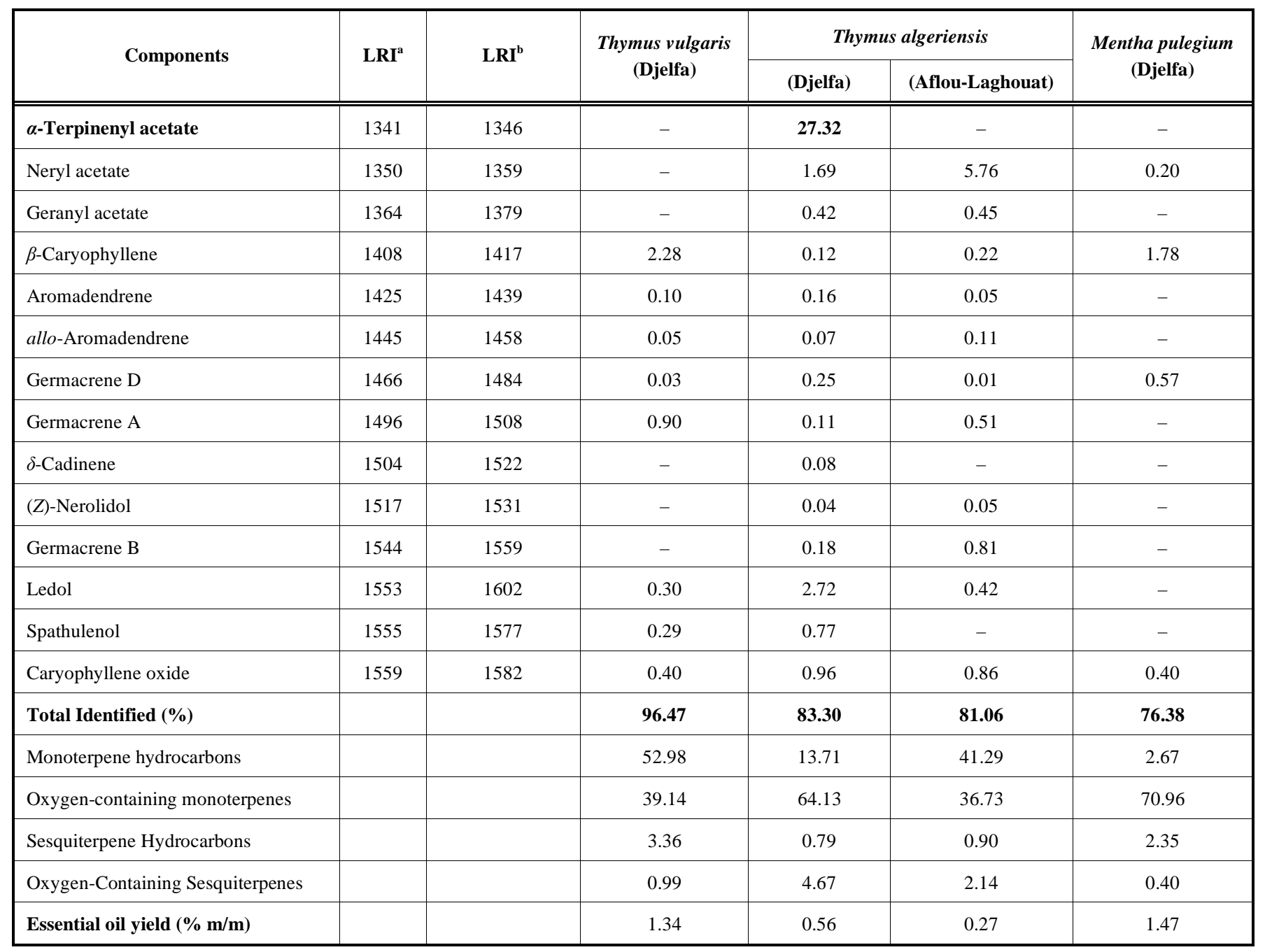

${ }^{a}$ LRI: Linear Retention Indices determined experimentally on apolar column DB-5.

${ }^{\mathrm{b}}$ LRI: Linear Retention Indices obtained from literature [20].

${ }^{\mathrm{c}}$ LRI: Linear Retention Indices obtained from literature [61].

Table 2. Antioxidant acitivity of the essential oil samples of Thymus vulgaris, Thymus algeriensis and Mentha pulegium using DPPH free radical scavenging.

\begin{tabular}{|c|c|}
\hline Essential Oil Sample & $\mathbf{E C}_{\mathbf{5 0}}(\mathbf{m g} / \mathbf{m L})$ \\
\hline \hline Thymus vulgaris & $2.3 \pm 0.1$ \\
\hline Thymus algeriensis (Djelfa) & $10.2 \pm 0.9$ \\
\hline Thymus algeriensis (Aflou) & $>45.0$ \\
\hline Mentha pulegium & $27.7 \pm 2.4$ \\
\hline Vitamin E & $0.0207 \pm 0.0007$ \\
\hline Ascorbic acid & $0.0078 \pm 0.0001$ \\
\hline Butylhydroxyanisole (BHA) & $0.0011 \pm 0.0003$ \\
\hline
\end{tabular}

\subsection{Antioxidant Activity}

\subsubsection{DPPH Assay}

Antioxidant activities of the different EO samples were evaluated using two complementary methods: the DPPH assay, and the phosphomolybdenum assay. The DPPH test measures the ability of the sample to provide protons, whereas the phosphomolybdenum assay measures the capacity of the sample to donate electrons.

The results of the tests of DPPH radical scavenging activities of the different samples on the EOs are shown in Table 2. These results are expressed as $\mathrm{EC}_{50}$ values, that are 
Table 3. Antioxidant acitivity of the essential oil samples of Thymus vulgaris, Thymus algeriensis and Mentha pulegium using Phosphomolybdenum assay.

\begin{tabular}{|c|c|}
\hline Essential Oil & AEAC $^{\mathbf{a}}(\mathbf{m g} / \mathbf{m L})$ \\
\hline \hline Thymus vulgaris (Djelfa) & $0.107 \pm 0.007$ \\
\hline Thymus algeriensis (Djelfa) & $0.220 \pm 0.022$ \\
\hline Thymus algeriensis (Aflou) & $0.148 \pm 0.003$ \\
\hline Mentha pulegium (Djelfa) & $0.159 \pm 0.002$ \\
\hline Vitamin E & $0.572 \pm 0.023$ \\
\hline
\end{tabular}

${ }^{\mathrm{a}}$ Antioxidant reducing power is expressed as AEAC (Ascorbic acid Equivalent Antioxidant Power).

defined as the concentration of substrate that causes 50\% loss of the concentration of the free radicals DPPH initially introduced; the higher the antioxidant activity, the lower is the value of $\mathrm{EC}_{50}$ [21]. In comparison with antioxidants of reference, the EO samples showed weak DPPH-radicalscavenging activities. Their activities can be classified as follows: T. vulgaris $>T$. algeriensis (Djelfa) $>M$. pulegium $>T$. algeriensis (Aflou-Laghouat). More effectively, T. vulgaris presented a very interesting $\mathrm{EC}_{50}$ value, and it could be considered active in comparison with the majority of common EOs.

\subsubsection{Phosphomolybdenum Assay}

The second test named Phosphomolybdenum test, measures the reducing power capacity in aqueous medium. Antioxidant reducing power is expressed as AEAC: Ascorbic acid Equivalent Antioxidant Power. By definition, AEAC is defined as the concentration of an antioxidant of reference (ascorbic acid in this case) in $\mathrm{mg} / \mathrm{mL}$, which gives the equivalent antioxidant power for a concentration of $1 \mathrm{mg} / \mathrm{mL}$ of the EO. High value of AEAC indicates high antioxidant capacity.

In comparison with vitamin $\mathrm{E}$, the EOs showed moderate antioxidant capacities (Table 3). The highest antioxidant capacity was observed for the EO of T. algeriensis (Djelfa); while the EO with the lowest activity was recorded for $T$. vulgaris. As a matter of fact, the EOs samples presented practically close values of antioxidant activities, and they were approximately 2 to 5 times lower than vitamin E; whereas, vitamin E presented almost two times lower antioxidant power than vitamin $\mathrm{C}$.

\subsection{Antimicrobial Activity}

\subsubsection{Disc Diffusion Test}

The antibacterial activities of the EOs were also investigated. Inhibition zone diameters are includes in Table $\mathbf{4}$ for the four EO samples (values are average of three repetitions). The results showed a sensitivity of the microorganisms towards all the EOs, with a remarquable resistance for Pseudomonas aeruginosa. This resistance was observed by Cosentino et al. [28] for the EOs of T. capitatus and T. herba barona, Bouhdid et al. [29] for three species of $T$. genus and Hussain et al. [30] for six plants within the Lamiaceae family. Let's mention that comparisons of results of the founded antimicrobial activities with those of literature "Tables $\mathbf{4}(\mathbf{c})$ and $\mathbf{5}(\mathbf{b})$ " are not evident since the evaluations conditions are somehow different.

T. vulgaris $\mathrm{EO}$ sample had the strongest activity with the highest inhibition zone diameters, while the EOs of $T$. algeriensis and M. pulegium showed moderate activities.

In a diffusion test, the inhibition zone diameter for a component is determined by its antimicrobial activity, its solubility and capacity of diffusion in the media and by the characteristics of the microorganism itself [31]. Diffusion methods are likely appreciated because their simplicity and low cost, but these methods are not always reliable for the evaluation of antimicrobial activities of plant extracts, because the absence of inhibition zone doesn't mean that the tested compound is inactive, especially for compounds with low polarity that diffuse slowly in the culture media [32].

\subsubsection{Minimal Inhibitory Concentration (MIC) and Bacte- ricidal Concentrations (MBC) Tests}

The determined MIC values were ranged from 0.127 $\mathrm{mg} / \mathrm{mL}$ (T. vulgaris $\mathrm{EO}$ for B. cereus and E. faecalis) to higher than $4.5 \mathrm{mg} / \mathrm{mL}$ (for Candida albicans for the two samples of $T$. algeriensis). The same resistance was observed for $P$. aeruginosa towards all the EO samples (Table 5).

$T$. vulgaris EO showed MICs values between 0.12 $\mathrm{mg} / \mathrm{mL}$ (for the strains B. cereus and E. faecalis) and 1.01 $\mathrm{mg} / \mathrm{mL}$ (for K. pneumoniae and S. aureus). The growth of MRSA, S. typhi and E. coli was inhibited at a concentration equal to $0.5 \mathrm{mg} / \mathrm{mL}$. The resistance of $P$. aeruginosa was observed even with a concentration of $2.03 \mathrm{mg} / \mathrm{mL}$. Imelouane et al. [33] found for this same species EO MIC values equal to $1.33 \mathrm{mg} / \mathrm{mL}$ for the strains $E$. coli, S. aureus and $S$. epidermidis. Kaloustian et al. [34] found MICs equal to 1 and $2 \mathrm{mg} / \mathrm{mL}$ for the strains $E$. coli and $S$. aureus respectively, while testing the EOs of T. vulgaris and T. zygis.

For the MBCs, B. cereus was the most sensitive strain, with MBC equal to $0.5 \mathrm{mg} / \mathrm{mL}$. MRSA, S. typhi, E. coli, $S$. aureus and $E$. faecalis were inhibited at an oil concentration of $1.01 \mathrm{mg} / \mathrm{mL}$. Many previous studies confirm the antimicrobial properties of EOs from Thymus genus [35-41], that is in correlation with our results. T. algeriensis EO showed a moderate to weak activity with more effectiveness on Gram positive bacteria (Table 6), this weak activity has been also observed by Hazzit et al. [42] for two samples of $T$. algeriensis.

\subsection{Antifungal Activity}

Inhibition growth percentages observed for the different EO samples against the filamentous fungi Fusarium oxysporum sp.f. albedinis are shown in Table 6. All the EO tested exhibited inhibition effects against the tested fungi. The EO of T. vulgaris showed the strongest activity with a fungistatic and fungicide concentration equal to 1.753 $\mathrm{mg} / \mathrm{mL}$, and $3.438 \mathrm{mg} / \mathrm{mL}$, respectively. While the EOs of $T$. algeriensis (Djelfa) and M. pulegium showed a moderate activity with MICs values equal to $8.963 \mathrm{mg} / \mathrm{mL}$ and 8.781 $\mathrm{mg} / \mathrm{mL}$, respectively. In another hand, these latest EOs did not exhibit any measured MFCs activity in the range of the concentration studied. These observed differences are proba- 
Table 4a. Antimicrobial activity of essential oil samples of Thymus vulgaris, Thymus algeriensis and Mentha pulegium by discdiffusion diameter inhibition zones.

\begin{tabular}{|c|c|c|c|c|}
\hline \multirow{2}{*}{ Essential Oil Plant } & \multirow{2}{*}{ Thymus vulgaris } & \multicolumn{2}{|c|}{ Thymus algeriensis } & \multirow{2}{*}{ Mentha pulegium } \\
\hline & & Djelfa & Aflou & \\
\hline \multirow[t]{2}{*}{ Essential oil concentration (mg/disc) } & 2.23 & 2.32 & 2.23 & 2.27 \\
\hline & \multicolumn{4}{|c|}{ Inhibition Zone Diameters $(\mathbf{m m})^{a}$} \\
\hline Klebsiella pneumoniae & $24,50 \pm 2,12$ & $16.00 \pm 1.41$ & $11.78 \pm 2.27$ & $10.33 \pm 2.31$ \\
\hline Pseudomonas aeruginosa & $9.00 \pm 0.00$ & $7.83 \pm 0.76$ & $7.50 \pm 0.71$ & $9.17 \pm 0.29$ \\
\hline Salmonella typhi & $24.00 \pm 1.41$ & $12.22 \pm 0.70$ & $16.67 \pm 1.15$ & $10.50 \pm 0.71$ \\
\hline Escherichia coli & $31.17 \pm 2.84$ & $13.88 \pm 1.24$ & $14.33 \pm 0.47$ & $10.75 \pm 0.35$ \\
\hline Bacillus cereus & $19.33 \pm 2.52$ & $17.54 \pm 0.30$ & $17.00 \pm 0.00$ & $11.33 \pm 1.53$ \\
\hline Staphylococcus aureus & $22.33 \pm 1.15$ & $8.33 \pm 0.58$ & $9.00 \pm 0.00$ & $9.22 \pm 1.07$ \\
\hline MRSA & $29.00 \pm 1.00$ & $14.17 \pm 1.18$ & $9.83 \pm 1.44$ & $9.33 \pm 1.15$ \\
\hline Enterococcus faecalis & $15.33 \pm 1.04$ & $8.33 \pm 0.58$ & $9.00 \pm 1.41$ & $9.00 \pm 1.41$ \\
\hline Candida albicans & $19.67 \pm 1.53$ & $10.33 \pm 2.31$ & $10.33 \pm 1.53$ & $7.50 \pm 0.71$ \\
\hline
\end{tabular}

${ }^{a}$ three repetitions average $\pm \mathrm{SD}$

Table 4b. Antimicrobial activity of the controls used by disc-diffusion diameter inhibition zones.

\begin{tabular}{|c|c|c|c|c|}
\hline & GM (10UI) & AMC $(10 \mu \mathrm{g})$ & OX1 (1 $\mu \mathrm{g})$ & E15 $(15 \mu \mathrm{g})$ \\
\hline & \multicolumn{4}{|c|}{ Inhibition Zone Diameters (mm) } \\
\hline Klebsiella pneumoniae & 9 & 9 & 0 & 10 \\
\hline Pseudomonas aeruginosa & 21 & 0 & 0 & 8 \\
\hline Salmonella typhi & 21 & 30 & 0 & 16 \\
\hline Escherichia coli & 31 & 24 & 0 & 15 \\
\hline Bacillus cereus & 31 & 28 & 18 & 33 \\
\hline Staphylococcus aureus & 22 & 32 & 24 & 29 \\
\hline MRSA & 12 & 22 & 16 & 0 \\
\hline Enterococcus faecalis & 23 & 25 & 0 & 29 \\
\hline
\end{tabular}

GM: Gentamicine ; UI: unité internationale ; AMC: Amoxicilline - acide clavulanique ; OX1: Oxacilline ;E15: Erythromycine.

Table 4c. Antimicrobial activity of essential oil samples of Thymus vulgaris, Thymus algeriensis and Mentha pulegium by discdiffusion diameter inhibition zones (values from literature).

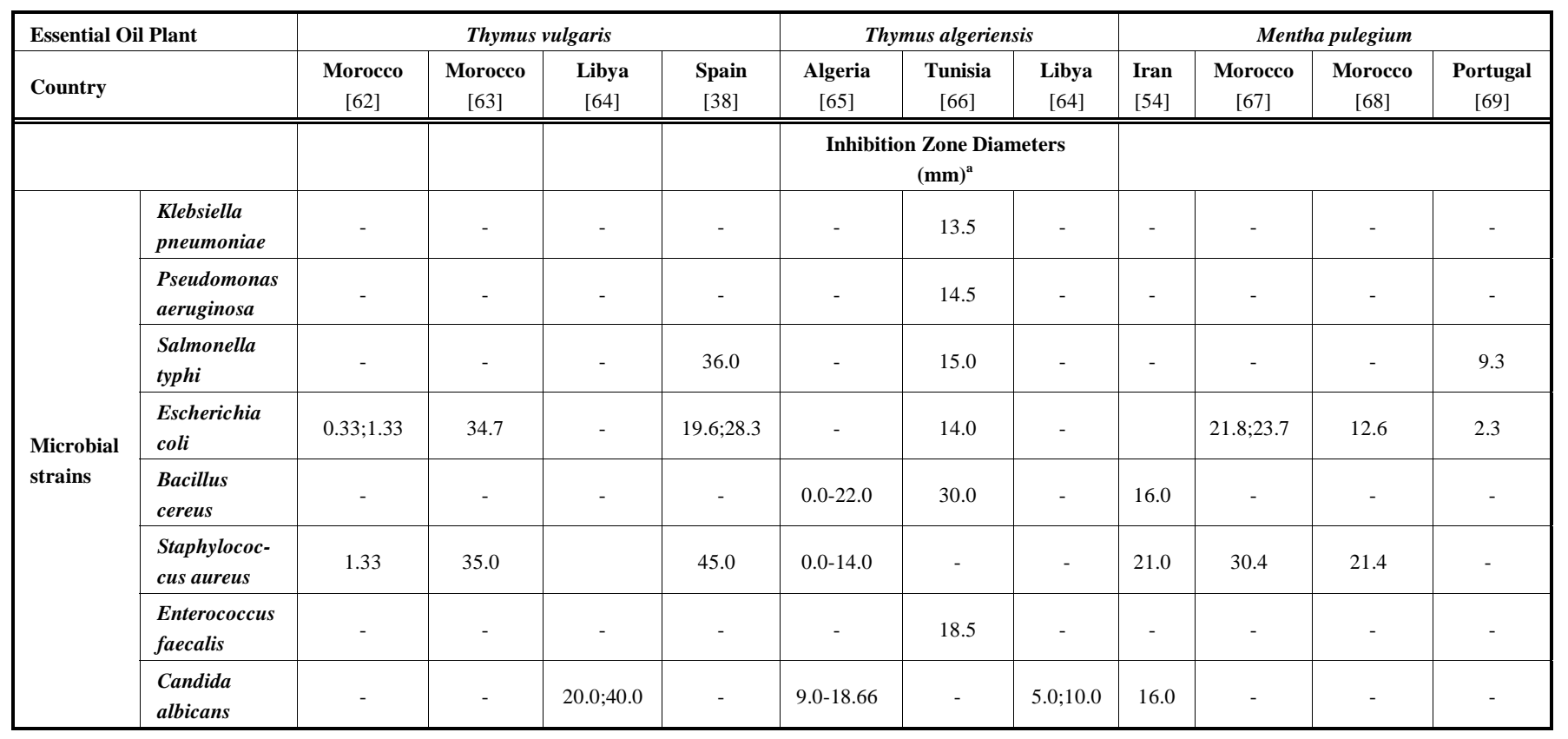


Table 5a. MIC and MBC for the essential oil samples of Thymus vulgaris, Thymus algeriensis and Mentha pulegium.

\begin{tabular}{|c|c|c|c|c|c|c|c|c|}
\hline \multirow{3}{*}{ Microbial Strains } & \multicolumn{2}{|c|}{ Thymus vulgaris } & \multicolumn{4}{|c|}{ Thymus algeriensis } & \multicolumn{2}{|c|}{ Mentha pulegium } \\
\hline & \multirow{2}{*}{$\begin{array}{c}\text { MIC } \\
(\mathrm{mg} / \mathrm{mL})\end{array}$} & \multirow{2}{*}{$\begin{array}{c}\text { MBC } \\
(\mathrm{mg} / \mathrm{mL})\end{array}$} & \multicolumn{2}{|c|}{ (Djelfa) } & \multicolumn{2}{|c|}{ (Aflou-Laghouat) } & \multirow{2}{*}{$\begin{array}{c}\text { MIC } \\
(\mathbf{m g} / \mathbf{m L})\end{array}$} & \multirow{2}{*}{$\begin{array}{c}\mathrm{MBC} \\
(\mathrm{mg} / \mathrm{mL})\end{array}$} \\
\hline & & & $\begin{array}{c}\text { MIC } \\
(\mathrm{mg} / \mathrm{mL})\end{array}$ & $\begin{array}{c}\text { MBC } \\
(\mathrm{mg} / \mathrm{mL})\end{array}$ & $\begin{array}{c}\text { MIC } \\
(\mathrm{mg} / \mathrm{mL})\end{array}$ & $\begin{array}{c}\text { MBC } \\
(\mathrm{mg} / \mathrm{mL})\end{array}$ & & \\
\hline Klebsiella pneumoniae & 1.016 & 2.032 & 2.114 & $>4.227$ & 2.030 & $>4.059$ & 2.070 & 2.070 \\
\hline Pseudomonas aeruginosa & $>2.032$ & $>2.032$ & $>4.227$ & $>4.227$ & $>4.059$ & $>4.059$ & $>2.485$ & $>2.485$ \\
\hline Salmonella typhi & 0.508 & 1.016 & 2.114 & 3.044 & 3.004 & 4.059 & 1.035 & 2.070 \\
\hline Escherichia coli & 0.508 & 1.016 & 3.044 & 4.227 & 3.004 & $>4.059$ & 1.035 & 1.035 \\
\hline Bacillus cereus & 0.127 & 0.508 & 0.264 & 0.528 & 1.015 & 1.015 & 1.035 & 2.485 \\
\hline Staphylococcus aureus & 1.016 & 1.016 & 1.057 & 1.057 & 1.015 & 1.015 & 1.035 & 2.070 \\
\hline MRSA & 0.508 & 1.016 & 0.528 & 3.044 & 1.015 & 2.030 & 1.035 & 2.070 \\
\hline Enterococcus faecalis & 0.127 & 1.016 & 0.528 & 1.057 & 0.507 & 1.015 & 1.035 & 2.070 \\
\hline Candida albicans & 0.564 & 1.129 & 4.697 & $>4.697$ & 4.510 & 4.510 & 1.150 & 2.301 \\
\hline
\end{tabular}

MIC: Minimum Inhibitory Concentration; MBC:Minimum Bactericide Concentration.

Table 5b. MIC (mg/mL) for the essential oil samples of Thymus vulgaris, Thymus algeriensis and Mentha pulegium (values from literature).

\begin{tabular}{|c|c|c|c|c|c|c|c|c|c|c|c|c|}
\hline \multirow{2}{*}{\multicolumn{2}{|c|}{$\begin{array}{c}\text { Plant } \\
\text { Country }\end{array}$}} & \multicolumn{4}{|c|}{ Thymus vulgaris } & \multicolumn{2}{|c|}{ Thymus algeriensis } & \multicolumn{5}{|c|}{ Mentha pulegium } \\
\hline & & $\begin{array}{c}\text { Libya } \\
{[64]}\end{array}$ & $\begin{array}{c}\text { Spain } \\
{[38]}\end{array}$ & $\begin{array}{r}\text { Iran } \\
{[70]}\end{array}$ & $\begin{array}{c}\text { Morocco } \\
{[63]}\end{array}$ & $\begin{array}{c}\text { Tunisia } \\
{[66]}\end{array}$ & $\begin{array}{c}\text { Libya } \\
{[64]}\end{array}$ & $\begin{array}{c}\text { Morocco } \\
{[71]}\end{array}$ & $\begin{array}{l}\text { Iran } \\
{[54]}\end{array}$ & $\begin{array}{c}\text { Morocco } \\
{[67]}\end{array}$ & $\begin{array}{c}\text { Morocco } \\
{[68]}\end{array}$ & $\begin{array}{c}\text { Portugal } \\
{[69]}\end{array}$ \\
\hline \multirow{8}{*}{$\begin{array}{c}\text { Microbial } \\
\text { strains }\end{array}$} & Klebsiella pneumoniae & - & - & - & - & 6.0 & - & - & - & - & - & - \\
\hline & Pseudomonas aeruginosa & 160.0 & - & - & - & 5.0 & 80.0 & - & - & - & - & - \\
\hline & Salmonella typhi & - & $<0.2$ & - & - & 6.0 & - & - & 4.0 & - & - & 3.8 \\
\hline & Escherichia coli & - & 0.5 & - & 9.3 & 6.0 & - & $2.0 ; 4.0$ & 4.0 & $4.0 ; 2.0$ & 1.0 & 3.2 \\
\hline & Bacillus cereus & - & - & - & - & 1.0 & - & - & 1.0 & - & - & - \\
\hline & Staphylococcus aureus & 80.0 & $<0.2$ & 0.05 & 10.7 & - & 20.0 & 2.0 & 0.5 & 2.0 & 1.0 & - \\
\hline & Enterococcus faecalis & 80.0 & & 0.05 & - & 3.0 & 80.0 & - & - & - & - & - \\
\hline & Candida albicans & - & - & - & - & - & - & - & 2.0 & - & - & - \\
\hline
\end{tabular}

bly due to the difference in the compositions between the EOs.

Soliman \& Badiaa [43] tested the antifungal effect of EOs of three species of Lamiaceae: $T$. vulgaris, $M$. viridis and Ocimum basilicum. They revealed that the three oils have inhibitory activities against the tested fungal species (Aspergillus flavus, A. parasiticus, A. ochraceus and Fusarium moniliforme). For the same family Dambolena et al. [44] found that several samples of Ocimum basilicum and Ocimum gratissimum have an antifungal activity against Fusarium verticillioides. Ouraïni et al. [45] obtained significant antifungal activity for EOs of $T$. saturejoides and $M$. pulegium. The antifungal potency of the EO of thyme has also been shown by Yang \& Clausen [46].

The results show that the extracts with high phenol concentration ( $T$. vulgaris) have strong antifungal activities. Several in vitro and in vivo studies conducted by Figueiredo et al. [47] showed that the EOs containing phenolic structures are very active against a wide spectrum of pathogenic fungi. The mechanism of toxicity of the phenols towards fungi is based on the inactivation of fungal enzymes. Phenolic terpene also act by binding to the amino groups of the microbial membrane proteins causing the alteration of the permeability and leakage of intracellular components [25]. This effect was also mentioned by Pinto et al. [48] by studying the EO of T. pulegioides effect on the membrane of Candida and Aspergillus.

\section{DISCUSSION}

\subsection{Essential Oil Yield and Chemical Composition}

According to previous reports [49], several chemotypes of $T$. vulgaris were determined: geraniol, $\alpha$-terpineol, sabinene hydrate (thuyanol), linalool, carvacrol, thymol and 1,8-cineole. Several species belonging to Thymus genera 


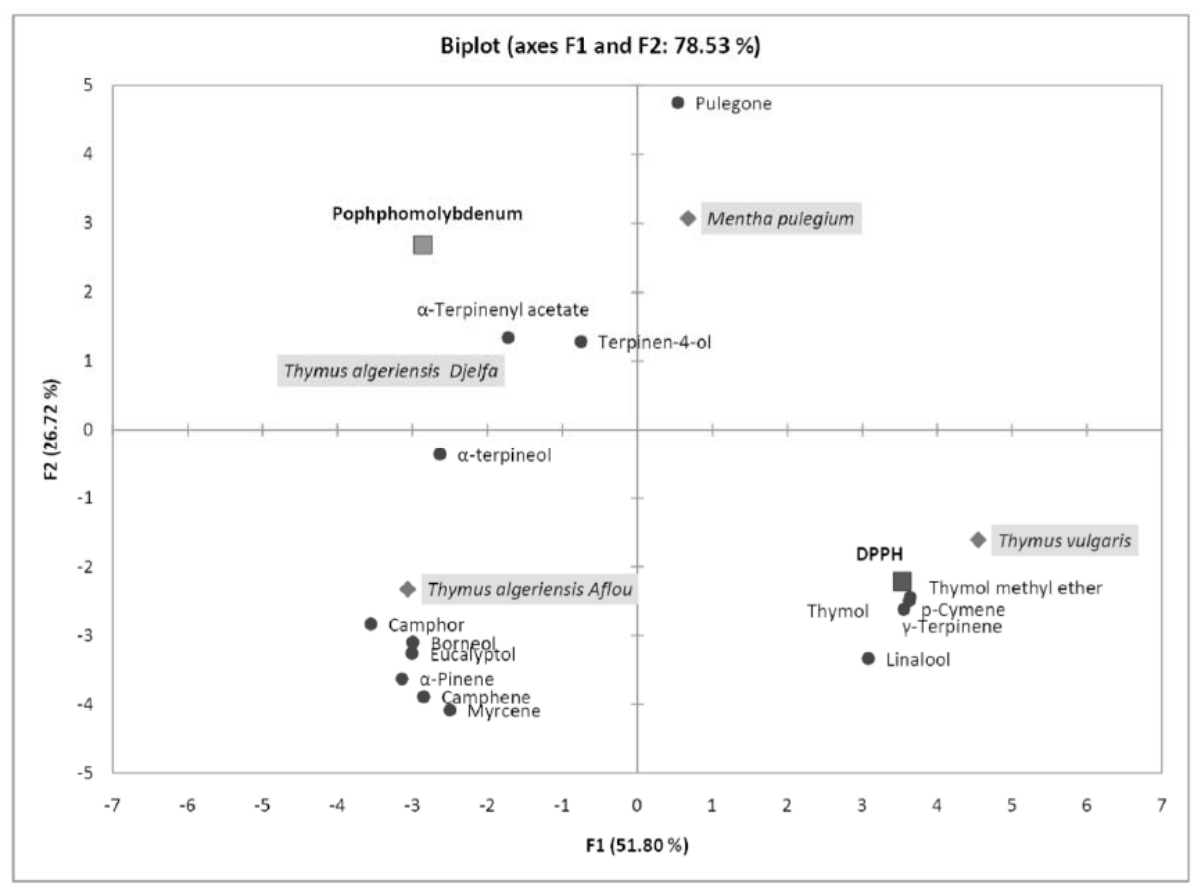

Fig. (1). Two dimensional plot on axes F1 and F2 of the essential oil samples end their antioxidant activities using Principal Component Analysis.

have similar compositions with a high content of phenolic terpenes (thymol or carvacrol) followed by a high percentage of $\gamma$-terpinene and $p$-cymene: $T$. hyemalys [50] T. pulegioides [48], T. capitatus and T. herba-barona [28].

Referring to literature, several major compounds were identified for the EO of this plant; previous studies confirm the predominance of pulegone as major compound: $73.40 \%$ on populations of Uruguay [51]; $85.40 \%$ on populations of Morocco [52]; while others have identified piperitone and piperitenone as the two dominant compounds [53, 54]. According to literature, three chemotypes have been established, pulegone type, piperitenone/piperitone type, and isomenthone / neoisomenthol type [55]. Beghidja et al. [56] studied the composition of several samples of pennyroyal from eastern Algeria, and claimed that these oils can be classified into two chemotypes: one of pulegone (pulegone with a percentage between 52 and $87 \%$ ), and a new chemotype poor in pulegone and rich of nonoxygenated terpenic fractions ( $\alpha$-pinene, $\alpha$-thujene, $\beta$-pinene, camphene, sabinene, $\beta$ phellandrene) and relatively high level of 1,8-cineol.

According to previous works which dealt with this plant from Algeria, it seems that there were some differences in the composition of the main compounds and which were related to the regions of collection [42, 57]. Indeed, Dob et al. identified for a sample of T. algeriensis (Medea - Algeria) the following major compounds: linalool (47.30\%), thymol (29.20\%) and p-cymene (6.80\%) [57]; While Hazzit et al. have suggested the existence of two chemotypes (samples were collected from the Chrea National Park, and the Chlef regions); the first was characterized by terpinyl acetate (18.00\%), trans-nerolidol (12.60\%), $\alpha$-pinene $(11.10 \%)$, borneol $(9.00 \%)$ and bornyl acetate $(7.70 \%)$, while the second has presented the following major compounds: terpinen4-ol $(10.60 \%)$, camphor $(10.10 \%), p$-cymene $(9.90 \%), \alpha-$ pinene $(6.50 \%)$ and 1,8-cineole $(6.50 \%)$ [42]. Comparing the founding of these In a matter of fact, the difference in composition of the EOs of $T$. algeriensis might be due to several factors, such as climate, season of harvest, stage of development and even genetic profiles of the species [26, 50, 58-60].

\subsection{Antioxidant Activity}

The obtained results suggested that when the EOs of the studied plants exhibited high antioxidant activity in term of DPPH assay, they simultaneously exhibited low activity in term of phosphomolebdenum assay; this finding could be explained by the different reactions mechanisms involved in each assay and related to different active chemicals in each case.

\subsubsection{DPPH Assay}

The antioxidant activity of the EO of T. vulgaris is found to be four times more active than the EO of T. algeriensis (Djelfa), and twelve times more active than the EO of $M$. pulegium.

Since the results of the investigated antioxidant activity showed a large variation in the values of $\mathrm{EC}_{50}$ and which were depending on the nature of the studied plant, it was mandatory to try to find a correlation between the chemical composition of the EOs and their antioxidant activity power AAP $\left(=1 / E_{50}\right)$ values. This was carried out by applying statistical methods involving Principal Component Analysis PCA (Fig. 1). It was found that highest value of AAP (as it was the case of $T$. vulgaris) was correlated with the previously major identified components: $p$-cymene, thymol, linalool, thymol-ethyl-ether and $\gamma$-terpinene. At the opposite, $T$. algeriensis and $M$. pulegium presented the lowest activities, and where each correlated with their main EOs components, i.e. $\alpha$-terpinenyl acetate and pulegone, respectively. Although, terpinen-4-ol and $\alpha$-terpineol were minor compo- 


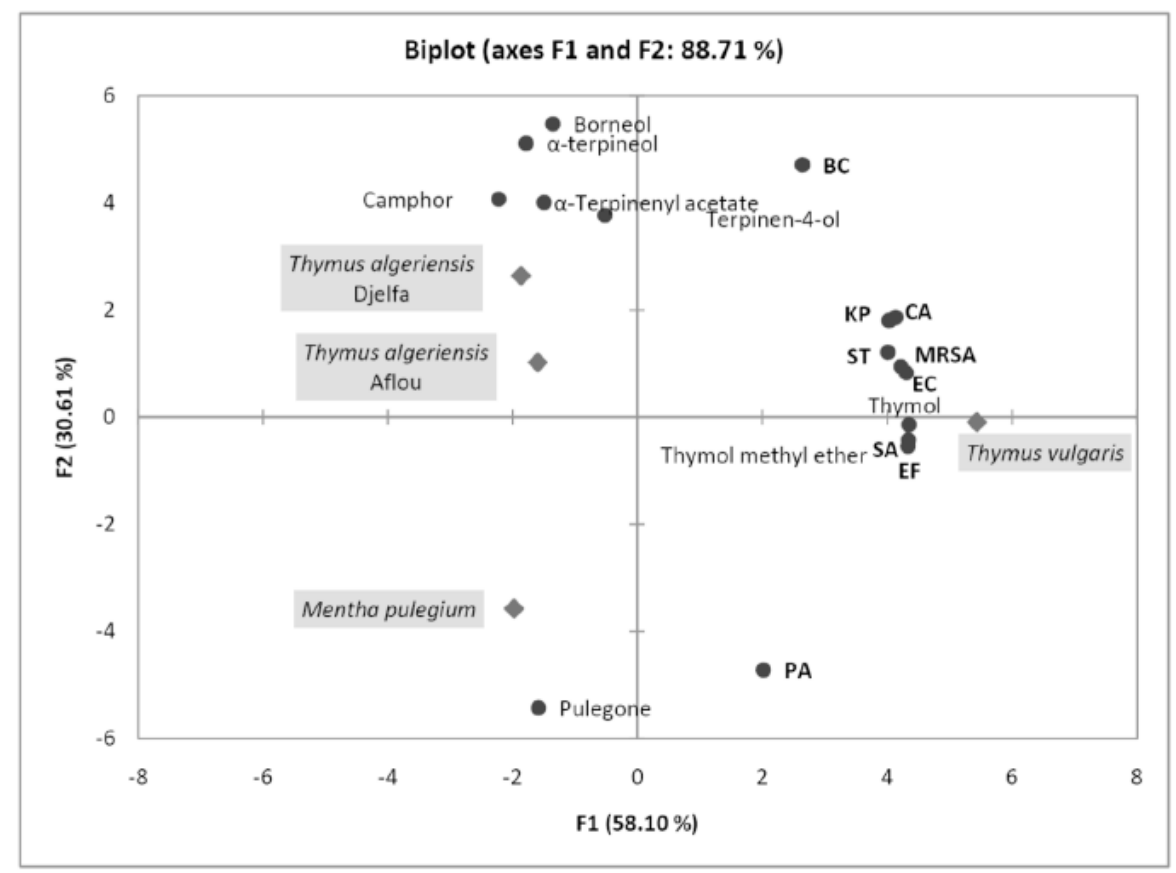

Fig. (2). Two dimensional plot on axes F1 and F2 of the essential oil samples end their antimicrobial activity (disk diffusion test) using Principal Component Analysis.

nents for $T$. algeriensis and $M$. pulegium, their relatively high percentages was also correlated with low antioxidant activity. Finally, T. algeriensis from Aflou, had presented practically no activity, and its EO was correlated with the presence of simultaneously higher percentages of $\alpha$-pinene, camphene, myrcene, eucalyptol, camphor and borneol.

\subsubsection{Phosphomolybdenum Assay}

First, let's mention that vitamin E (antioxidant of reference) which was used for comparison is almost 2 times less active than ascorbic acid (Table 3 ). Second, the values of the antioxidant power for this assay were completely different to those found using DPPH assay. This time, T. algeriensis (Aflou) and $M$. pulegium presented almost similar activities and were the most active EOs (6 to 7 times less active than ascorbic acid). At the opposite, $T$. vulgaris EO exhibited the lowest antioxidant power (almost 10 times less active than ascorbic acid).

It was found that highest reduction power of the EOs of T. algeriensis (Djelfa) is highly correlated with $\alpha$-terpinenyl acetate, terpinen-4-ol and $\alpha$-terpineol. In another hand both T. algeriensis (Aflou) and M. pulegium with practically close reduction powers were correlated positively with different components: $\alpha$-pinene, camphene, myrcene, eucalyptol, camphor and borneol for T. algeriensis (Aflou); and only pulegone for $M$. pulegium. At the contrary, $T$. vulgaris with the lowest reduction power was related to higher percentages of $p$-cymene, thymol, linalool, thymol-ethyl-ether and $\gamma$ terpinene.

\subsection{Antimicrobial Activity}

According to Fig. 2, the T. vulgaris was found to be the most active EO and exhibited important resistance against most of studied bacteria: Staphylococcus aureus, Escherichia coli, Salmonella typhi, Klebsiella pneumoniae and Candida albicans. According to PCA analysis, this activity is due mainly to presence of thymol and thymol-methyl-ether. Alternatively, the activity against Bacillus cereus was correlated with high percentages of camphor, borneol, $\alpha$ terpinenyl acetate, terpinen-4-ol and $\alpha$-terpineol. Finally, the relatively slight improvement of activity of $M$. pulegium $\mathrm{EO}$ against Pseudomonas aeruginosa is probably due to the presence of the high percentage of pulegone. As a result, and based on the PCA, it seems that pulegone does not contribute to any practical antimicrobial activity, since high percentage of pulegone imply slight improvement of this activity.

\subsubsection{Disc Diffusion Test}

The analysis of the simultaneous values of MIC and MIB with the chemical composition of the EOs against different bacteria using PCA revealed that the most active EOs plants were those of $T$. algeriensis (Djelfa \& Aflou) (Fig. 3). This strong activity was in strong correlation with several chemicals: eucalyptol, camphor, myrcene, $\alpha$-pinene, camphene, $\alpha$ terpineol, $\alpha$-terpinenyl acetate and terpinen-4-ol. For $M$. pulegium where its EO presented relatively moderate activity (MBC) against Bacillus cereus, Staphylococcus aureus and Enterococcus faecalis; this moderate activity is believed to be correlated to high content of pulegone.

\subsubsection{Antifungal Activity}

It was found that the EOs were exhibiting high MIC and at the same time presenting low or undetected activities in term of MIB values.

The results of PCA showed (Fig. 4), that the highest MIC values were correlated for different sets of EOs components for both T. algeriensis (Djelfa) and M. pulegium. Moreover, for almost the same components observed previously with disc diffusion test, the high MIC value for M. pulegium was attributed to the high composition of pulegone, but for $T$. 


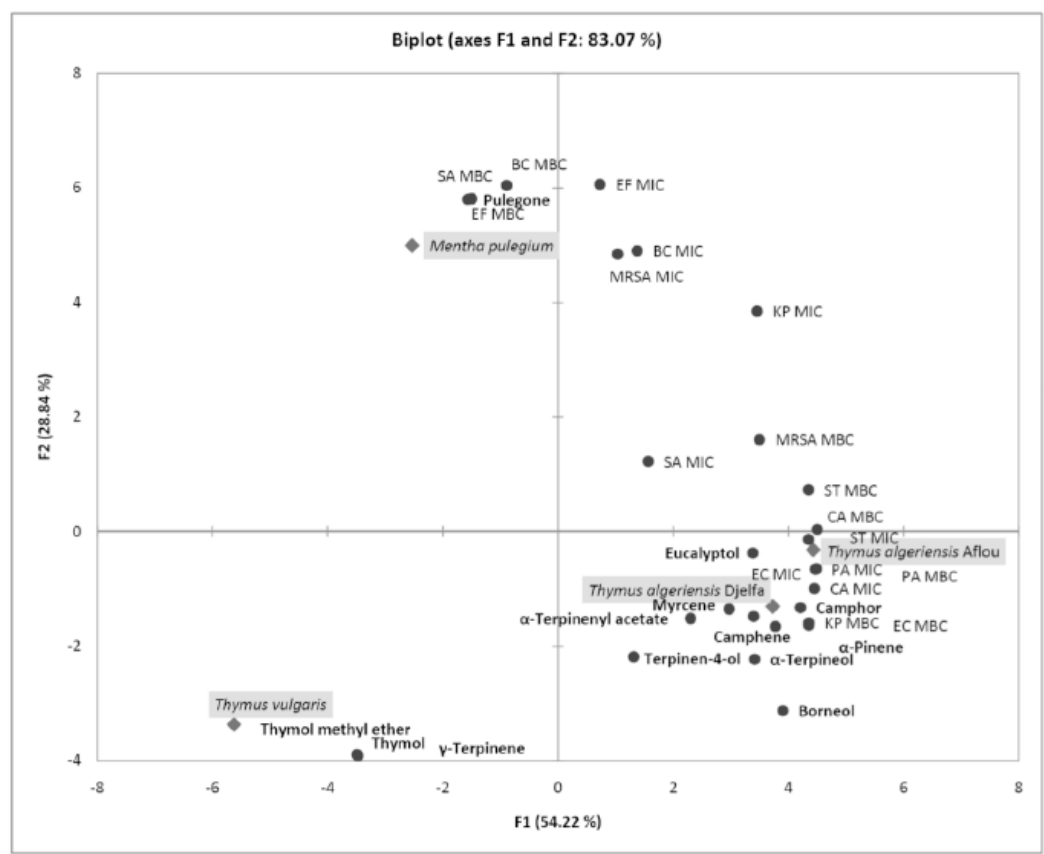

Fig. (3). Two dimensional plot on axes F1 and F2 of the essential oil samples end their antimicrobial activity (minimal inhibitory and bactericidal concentrations) using Principal Component Analysis.

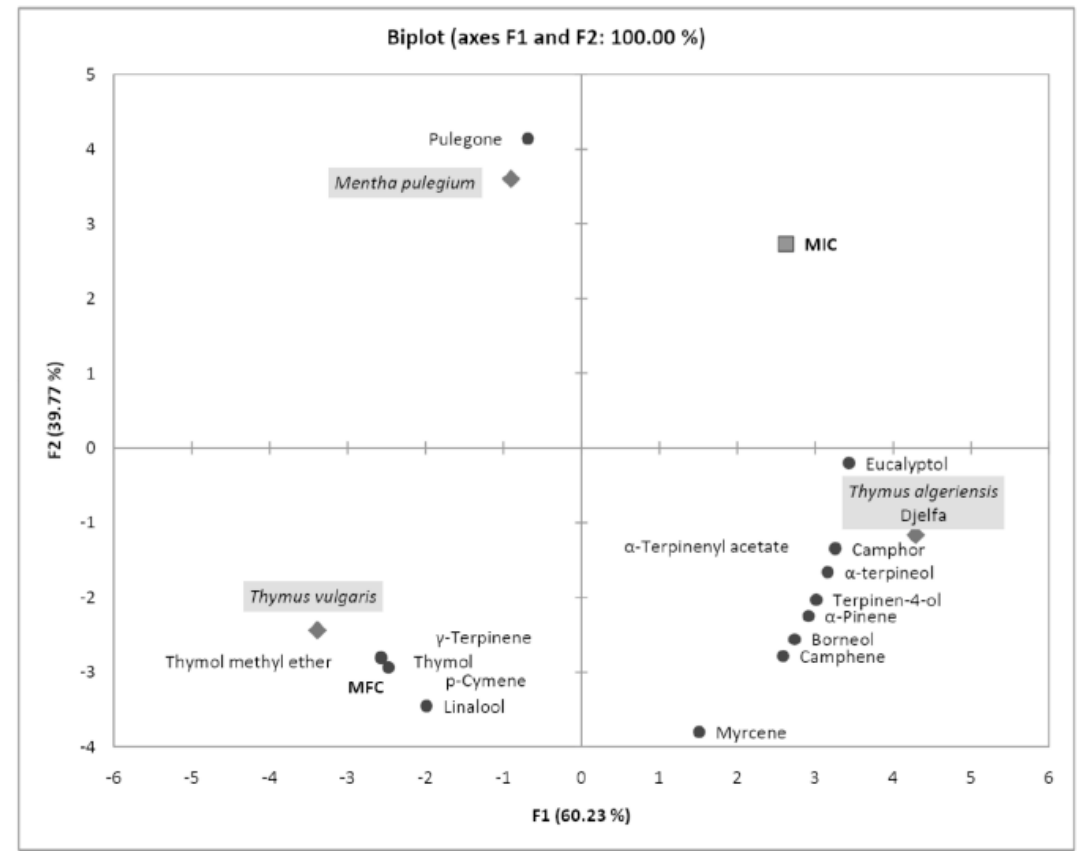

Fig. (4). Two dimensional plot on axes F1 and F2 of the essential oil samples end their antifungal activity using Principal Component Analysis.

algeriensis (Djelfa) it was due to the presence of eucalyptol, $\alpha$-terpinenyl acetate, terpinen-4-ol, $\alpha$-terpineol, $\alpha$-pinene, borneol and camphene. The EO of T. vulgaris with the lowest value of MIC was correlated with the following components: thymol-ethyl-ether, $\gamma$-terpinene, thymol, $p$-cymene and linalool. At the opposite, the EO of this later plant presented a good MFC value in comparison with the rest of the studied plants, in which they did not offer any measurable activity in the range of the studied concentrations. This high activity is due to the presence of thymol-ethyl-ether, $\gamma$-terpinene, thymol, $p$-cymene and linalool.

\section{CONCLUSION}

As a conclusion, the EOs tested in this study showed moderate to strong antioxidant and antimicrobial activities. Almost all EOs exhibited a radical scavenging activity (DPPH assay), with different values of $\mathrm{EC}_{50}$. T. vulgaris $\mathrm{EO}$ had the lowest value of $\mathrm{EC}_{50}$ which makes it the strongest EO among the tested samples. For antimicrobial activity, all the samples had inhibited the growth of the tested microbial strains, with the strongest antibacterial and antifungal activity attributed to $T$. vulgaris EO. The study of the relation 
between the chemical composition of the EOs and the antioxidant or the antimicrobial activity revealed the presence of different strong correlations with some major identified compounds in each case of study. It could be concluded that, thyme, T. vulgaris EO were effective as antioxidant activity due, in part, to the presence of several compounds, like thymol, thymol-methyl-ether, linalool and carverol, in their chemical compositions. They could be used as flavoring agents and good sources of antioxidants in making food with healthy benefits and good sensory acceptability. Further studies are required to collect more data about the toxicity of these EOs.

\section{CONFLICT OF INTEREST}

The authors confirm that this article content has no conflict of interest.

\section{ACKNOWLEDGEMENTS}

The authors wish to thank the Algerian Ministry of High Education and Scientific Research for funding the Research Laboratory of Fundamental Sciences-Laghouat, Algeria.

\section{REFERENCES}

[1] Gurib-Fakim A. Medicinal plants: traditions of yesterday and drugs of tomorrow. Mol Aspects Med 2006; 27: 1-93.

[2] Nostro A, Germano M, D'angelo V, et al. Extraction methods and bioautography for evaluation of medicinal plant antimicrobial activity. Lett Appl Microbiol 2000; 30(5): 379-84.

[3] Kulisic T, Radonic A, Katalinic V, et al. Use of different methods for testing antioxidative activity of oregano essential oil. Food Chem 2004; 85(4): 633-40.

[4] Chouliara E, Karatapanis A, Savvaidis I, et al. Combined effect of oregano essential oil and modified atmosphere packaging on shelflife extension of fresh chicken breast meat, stored at $4{ }^{\circ} \mathrm{C}$. Food Microbiol 2007; 24(6): 607-17.

[5] Gómez-Estaca J, de Lacey AL, López-Caballero M, et al. Biodegradable gelatin-chitosan films incorporated with essential oils as antimicrobial agents for fish preservation. Food Microbiol 2010; 27(7): 889-96.

[6] Holley RA, Patel D. Improvement in shelf-life and safety of perishable foods by plant essential oils and smoke antimicrobials. Food Microbiol 2005; 22(4): 273-92.

[7] Silva LF, das Graças Cardoso M, Batista LR, et al. Chemical characterization, antibacterial and antioxidant activities of essential oils of Mentha viridis L. and Mentha pulegium L. (L). Am J Plant Sci 2015; 6(5): 666.

[8] Grigore A, Paraschiv I, Colceru-Mihul S, et al. Chemical composition and antioxidant activity of Thymus vulgaris $\mathrm{L}$. volatile oil obtained by two different methods. Rom Biotechnol Lett 2010; 15(4): 5436-43.

[9] Ramadan KM, Ashoush I, El-Batawy O. Comparative evaluation of three essential oils as functional antioxidants and natural flavoring agents in ice cream. World Appl Sci J 2013; 23(2): 159-66.

[10] Rustaiyan A, Masoudi S, Monfared A, et al. Volatile constituents of three Thymus species grown wild in Iran. Planta Med 2000; 66(02): 197-8.

[11] Marino M, Bersani C, Comi G. Antimicrobial activity of the essential oils of Thymus vulgaris L. measured using a bioimpedometric method. J Food Prot 1999; 62(9): 1017-23.

[12] Pina-Vaz C, Gonçalves Rodrigues A, Pinto E, et al. Antifungal activity of Thymus oils and their major compounds. J Eur Acad Dermatol Venereol 2004; 18(1): 73-8.

[13] Simandi B, Hajdu V, Peredi K, et al. Antioxidant activity of pilot-plant alcoholic and supercritical carbon dioxide extracts of thyme. Eur J Lipid Sci Technol 2001; 103(6): 355-8.

[14] Soković M, Glamočlija J, Ćirić A, et al. Antifungal activity of the essential oil of Thymus vulgaris L. and thymol on experimentally induced dermatomycoses. Drug Dev Ind Pharm 2008; 34(12): 1388-93.

[15] Soković MD, Vukojević J, Marin PD, et al. Chemical composition of essential oils of Thymus and Mentha species and their antifungal activities. Molecules 2009; 14(1): 238-49.

[16] Baba-Aissa F. Encyclopédie des plantes utiles: Flore méditerranéenne (Maghreb,Europe méridionale) Substances végétales d'Afrique, d'Orient dt d'Occident: Alger : El Maarifa; 2011.

[17] Nikolić M, Glamočlija J, Ferreira IC, et al. Chemical composition, antimicrobial, antioxidant and antitumor activity of Thymus serpyllum L., Thymus algeriensis Boiss. and Reut and Thymus vulgaris $\mathrm{L}$. essential oils. Ind Crops Prod 2014; 52: 183-90.

[18] Beloued A. Plantes médicinales d'Algérie: Alger: Offices des publications universitaires; 2001.

[19] Boukhebti H, Chaker AN, Belhadj H, et al. Chemical composition and antibacterial activity of Mentha pulegium L. and Mentha spicata L. essential oils. Der Pharmacia Lett 2011;3(4): 267-75.

[20] Adams RP. Identification of essential oil components by gas chromatography/ mass spectrometry, $4^{\text {th }}$ ed. Allured Publishing Corporation: Illinois 2007; pp. 804.

[21] Molyneux P. The use of the stable free radical diphenylpicrylhydrazyl (DPPH) for estimating antioxidant activity. Songklanakarin J Sci Technol 2004; 26(2): 211-9.

[22] Prietto P, Pineda M, Aquilar M. Spectrophotometric quantification of antioxidant capacity through the formation of phosphomolybdenum complex: Specification application to the determination of vitamin E. Anal Biochem 1999; 269: 337-41.

[23] De Billerbeck V-G. Huiles essentielles et bactéries résistantes aux antibiotiques. Phytothérapie 2007; 5(5): 249-53.

[24] Cao L, Si JY, Liu Y, et al. Essential oil composition, antimicrobial and antioxidant properties of Mosla chinensis Maxim. Food Chem 2009; 115(3): 801-5.

[25] El Ajjouri M, Satrani B, Ghanmi M, et al. Activité antifongique des huiles essentielles de Thymus bleicherianus Pomel et Thymus capitatus (L.) Hoffm. \& Link contre les champignons de pourriture du bois d'oeuvre. Biotechnologie Agronomie Société Et Environ 2008; 12(4): $345-51$.

[26] Amarti F, Satrani B, Ghanmi M, et al. Composition chimique et activité antimicrobienne des huiles essentielles de Thymus algeriensis Boiss. \& Reut. et Thymus ciliatus (Desf.) Benth. du Maroc. Biotechnologie Agronomie Société Et Environ 2010; 14(1): 141-8.

[27] Zouari N, Fakhfakh N, Zouari S, et al. Chemical composition, angiotensin I-converting enzyme inhibitory, antioxidant and antimicrobial activities of essential oil of Tunisian Thymus algeriensis Boiss. et Reut.(Lamiaceae). Food Bioprod Process 2011; 89(4): 257-65.

[28] Cosentino S, Tuberoso C, Pisano B, et al. In-vitro antimicrobial activity and chemical composition of Sardinian thymus essential oils. Lett Appl Microbiol 1999; 29(2): 130-5.

[29] Bouhdid S, Idaomar M, Zhiri A, et al., editors. Thymus essential oils: Chemical composition and in vitro antioxidant and antibacterial activities. Congrès International de Biochimie: Biochimie, Substances Naturelles et Environnement 2006 9-12 ; Agadir, Morocco.

[30] Hussain AI, Anwar F, Nigam PS, et al. Antibacterial activity of some Lamiaceae essential oils using resazurin as an indicator of cell growth. LWT-Food Sci Technol 2011; 44(4): 1199-206.

[31] Carson C, Riley T. Antimicrobial activity of the major components of the essential oil of Melaleuca alternifolia. J Appl Bacteriol 1995; 78(3): 264-9.

[32] Klančnik A, Piskernik S, Jeršek B, et al. Evaluation of diffusion and dilution methods to determine the antibacterial activity of plant extracts. J Microbiol Methods 2010; 81(2): 121-6.

[33] Imelouane B, Amhamdi H, Wathelet JP, et al. Chemical composition and antimicrobial activity of essential oil of thyme (Thymus vulgaris) from Eastern Morocco. Int J Agric Biol 2009; 11(2): 2058.

[34] Kaloustian J, Chevalier J, Mikail C, et al. Étude de six huiles essentielles: Composition chimique et activité antibactérienne. Phytothérapie 2008; 6(3): 160-4.

[35] Govaris A, Botsoglou E, Sergelidis D, et al. Antibacterial activity of oregano and thyme essential oils against Listeria monocytogenes and Escherichia coli O157: $\mathrm{H} 7$ in feta cheese packaged under modified atmosphere. LWT-Food sci technol 2011; 44(4): 1240-4. 
[36] Kabouche Z, Boutaghane N, Laggoune S, et al. Comparative antibacterial activity of five Lamiaceae essential oils from Algeria. Int J Aromatherapy 2005; 15(3): 129-33.

[37] Naeini A, Khosravi A, Chitsaz M, et al. Anti-Candida albicans activity of some Iranian plants used in traditional medicine. J Med Mycol 2009; 19(3): 168-72.

[38] Rota MC, Herrera A, Martínez RM, et al. Antimicrobial activity and chemical composition of Thymus vulgaris, Thymus zygis and Thymus hyemalis essential oils. Food Control 2008; 19(7): 681-7.

[39] Saad A, Fadli M, Bouaziz M, et al. Anticandidal activity of the essential oils of Thymus maroccanus and Thymus broussonetii and their synergism with amphotericin B and fluconazol. Phytomedicine 2010; 17(13): 1057-60.

[40] Smith-Palmer A, Stewart J, Fyfe L. Antimicrobial properties of plant essential oils and essences against five important food-borne pathogens. Lett Appl Microbiol 1998; 26(2): 118-22.

[41] Tohidpour A, Sattari M, Omidbaigi R, et al. Antibacterial effect of essential oils from two medicinal plants against Methicillinresistant Staphylococcus aureus (MRSA). Phytomedicine 2010; 17(2): 142-5.

[42] Hazzit M, Baaliouamer A, Veríssimo A, et al. Chemical composition and biological activities of Algerian Thymus oils. Food Chem 2009; 116(3): 714-21.

[43] Soliman K, Badeaa R. Effect of oil extracted from some medicinal plants on different mycotoxigenic fungi. Food Chem Toxicol 2002; 40(11): 1669-75.

[44] Dambolena JS, Zunino MP, López AG, et al. Essential oils composition of Ocimum basilicum L. and Ocimum gratissimum L. from Kenya and their inhibitory effects on growth and fumonisin production by Fusarium verticillioides. Innov Food Sci Emerg Technol 2010; 11(2): 410-4.

[45] Ouraïni D, Agoumi A, Ismaïli-Alaoui M, et al. Activité antifongique de l'acide oléique et des huiles essentielles de Thymus saturejoides L. et de Mentha pulegium L., comparée aux antifongiques dans les dermatoses mycosiques. Phytothérapie 2007; 5(1): 6-14.

[46] Yang VW, Clausen CA. Antifungal effect of essential oils on southern yellow pine. Int Biodeterior Biodegrad 2007; 59(4): 3026.

[47] Figueiredo A, Barroso J, Pedro L, et al. Portuguese Thymbra and Thymus species volatiles: chemical composition and biological activities. Curr Pharm Des 2008; 14(29): 3120-40.

[48] Pinto E, Pina-Vaz C, Salgueiro L, et al. Antifungal activity of the essential oil of Thymus pulegioides on Candida, Aspergillus and dermatophyte species. J Med Microbiol 2006; 55(10): 1367-73.

[49] Keefover-Ring K, Thompson JD, Linhart YB. Beyond six scents: Defining a seventh Thymus vulgaris chemotype new to southern France by ethanol extraction. Flavour Fragrance J 2009; 24(3): 117-22.

[50] Jordán M, Martínez R, Goodner K, et al. Seasonal variation of Thymus hyemalis Lange and Spanish Thymus vulgaris L. essential oils composition. Ind Crops Prod 2006; 24(3): 253-63.

[51] Lorenzo D, Paz D, Dellacassa E, et al. Essential oils of Mentha pulegium and Mentha rotundifolia from Uruguay. Braz Arch Biol Technol 2002; 45(4): 519-24.

[52] Bouchra C, Achouri M, Hassani LI, et al. Chemical composition and antifungal activity of essential oils of seven Moroccan Labiatae against Botrytis cinerea Pers: Fr. J Ethnopharmacol 2003; 89(1): $165-9$.

[53] Derwich E, Benziane Z, Taouil R, et al. Comparative essential oil composition of leaves of Mentha rotundifolia and Mentha pulegium a traditional herbal medicine in Morocco. American-Eurasian J Sustain Agric 2010; 4(1): 47-54.

[54] Mahboubi M, Haghi G. Antimicrobial activity and chemical composition of Mentha pulegium L. essential oil. J Ethnopharmacol 2008; 119(2): 325-7.
[55] Stoyanova A, Georgiev E, Kula J, et al. Chemical composition of the essential oil of Mentha pulegium L. from Bulgaria. J Essent Oil Res 2005; 17(5): 475-6.

[56] Beghidja N, Bouslimani N, Benayache F, et al. Composition of the oils from Mentha pulegium grown in different areas of the East of Algeria. Chem Nat Compd 2007; 43(4): 481-3.

[57] Dob T, Dahmane D, Benabdelkader T, et al. Studies on the essential oil composition and antimicrobial activity of Thymus algeriensis Boiss. et Reut. Int J Aromatherapy 2006; 16(2): 95-100.

[58] İnan M, Kirpik M, Kaya DA, et al. Effect of harvest time on essential oil composition of Thymbra spicata L. growing in flora of Adiyaman. Adv Environ Biol 2011; 5(2): 356-8.

[59] Sellami IH, Maamouri E, Chahed T, et al. Effect of growth stage on the content and composition of the essential oil and phenolic fraction of sweet marjoram (Origanum majorana L.). Ind Crops Prod 2009; 30(3): 395-402.

[60] Telci I, Demirtas I, Bayram E, et al. Environmental variation on aroma components of pulegone/piperitone rich spearmint (Mentha spicata L.). Ind Crops Prod 2010; 32(3): 588-92.

[61] Senatore F, Urrunaga Soria E, Urrunaga Soria R, et al. Essential oil of Eremocharis triradiata (Wolff.) Johnston (Apiaceae) growing wild in Peru. Flavour Fragrance J 1997; 12(4): 257-9.

[62] Imelouane B, Amhamdi H, Wathelet J-P, et al. Chemical composition and antimicrobial activity of essential oil of thyme (Thymus vulgaris) from Eastern Morocco. Int J Agric Biol 2009; 11(2): 2058.

[63] Zantar S, Haouzi R, Chabbi M, et al. Effect of gamma irradiation on chemical composition, antimicrobial and antioxidant activities of Thymus vulgaris and Mentha pulegium essential oils. Radiat Phys Chem 2015; 115(0): 6-11.

[64] Nikolić M, Glamočlija J, Ferreira ICFR, et al. Chemical composition, antimicrobial, antioxidant and antitumor activity of Thymus serpyllum L., Thymus algeriensis Boiss. and Reut and Thymus vulgaris L. essential oils. Ind Crops Prod 2014; 52(0): 183-90.

[65] Hazzit M, Baaliouamer A, Veríssimo AR, et al. Chemical composition and biological activities of Algerian Thymus oils. Food Chem 2009; 116(3): 714-21.

[66] Zouari N, Fakhfakh N, Zouari S, et al. Chemical composition, angiotensin I-converting enzyme inhibitory, antioxidant and antimicrobial activities of essential oil of Tunisian Thymus algeriensis Boiss. et Reut. (Lamiaceae). Food Bioprod Process 2011; 89(4): 257-65.

[67] Cherrat L, Espina L, Bakkali M, et al. Chemical composition, antioxidant and antimicrobial properties of Mentha pulegium, Lavandula stoechas and Satureja calamintha Scheele essential oils and an evaluation of their bactericidal effect in combined processes. Innov Food Sci Emerg Technol 2014; 22(0): 221-9.

[68] Ait-Ouazzou A, Lorán S, Arakrak A, et al. Evaluation of the chemical composition and antimicrobial activity of Mentha pulegium, Juniperus phoenicea, and Cyperus longus essential oils from Morocco. Food Res Int 2012; 45(1): 313-9.

[69] Teixeira B, Marques A, Ramos C, et al. European pennyroyal (Mentha pulegium) from Portugal: Chemical composition of essential oil and antioxidant and antimicrobial properties of extracts and essential oil. Ind Crops Prod 2012; 36(1): 81-7.

[70] Nezhadali A, Nabavi M, Rajabian M, et al. Chemical variation of leaf essential oil at different stages of plant growth and in vitro antibacterial activity of Thymus vulgaris Lamiaceae, from Iran. BeniSuef Univ J Basic Appl Sci 2014; 3(2): 87-92.

[71] Cherrat L, Espina L, Bakkali M, et al. Chemical composition, antioxidant and antimicrobial properties of Mentha pulegium, Lavandula stoechas and Satureja calamintha Scheele essential oils and an evaluation of their bactericidal effect in combined processes. Innov Food Sci Emerg Technol 2014; 22: 221-9. 